\title{
IDENTIFIKASI PERMASALAHAN PEMBELAJARAN MAHASISWA PENDIDIKAN MATEMATIKA PADA MATA KULIAH PROGRAM LINEAR: STUDI KASUS PADA PROGRAM STUDI PENDIDIKAN MATEMATIKA
}

\author{
Lalu Saparwadi ${ }^{1}$ dan Qurratul Aini ${ }^{2}$ \\ 1 Prodi Pendidikan Matematika STKIP Hamzanwadi Selong, NTB, Indonesia \\ 2 Prodi Pendidikan Ekonomi STKIP Hamzanwadi Selong, NTB, Indonesia \\ Email: lalusaparwadi@gmail.com
}

\begin{abstract}
Abstrak
Penelitian ini memfokuskan pada identifikasi masalah dalam pembelajaran program linear untuk mahasiswa program studi pendidikan matematika yang sedang mengikuti perkuliahan pada semester genap perguruan tinggi di pulau Lombok. Penelitian ini merupakan penelitian kualitatif dekriptif dengan menggunakan aturan penelitian pengembangan. Populasi penelitian ini adalah seluruh mahasiswa Program Studi Pendidikan Matematika PTN/PTS se-pulau Lombok dan yang menjadi sasaran penelitian, yaitu (1) mahasiswa yang sedang mengikuti matakuliah program linear; (2) dosen pengampu matakuliah program linear. Teknik pengumpulan data yang akan diterapkan dalam penelitian ini adalah wawancara, analisis dokumen, dan observasi. Berdasarkan teknik pengumpulan data tersebut, dapat diperoleh data kualitatif dan dianalisis dengan menggunakan teknik analisis deskripsi. Untuk mencapai tujuan tersebut, maka kegiatan yang dilakukan meliputi identifikasi masalah, kebutuhan dalam pelaksanaan pembelajaran, dan manfaat yang diperoleh setelah mengikuti pembelajaran program linear. Berdasarkan hasil penelitian diperoleh: a) buku yang membahas khusunya masalah program linear masih cukup sulit ditemukan sebagai refrensi, b) mahasiswa mengalami kesulitan dalam mendefinisikan masalah ke dalam model matematika, c) Strategi yang digunakan oleh dosen selama ini dalam pembelajaran program linear sebagian besar mahasiswa gagal dalam menerjemahkan masalah menjadi model matematika, dan d) mahasiswa tidak tau manfaat secara aplikasi setelah mempelajari program linear.
\end{abstract}

Kata kunci: Program Linear, Model Matemaika, Grafik.

\begin{abstract}
The recent study identifies student learning problem on the course of linear program for students at mathematics department. The population is taken from students of mathematics department in Lombok West Nusa Tenggara. The findings show that there are four types of problem faced by students when learning Linear Program, such as: a) the lack number of references relating to the course, b) difficulties in modeling problem to mathematics model, c) teaching strategies causes student difficulties in in modeling problem to mathematics model, and d) students have no idea yet relating to the application of the course.
\end{abstract}

Keywords: Linear Program, Mathematics Modeling, Graphic 
Saparwadi, L. \& Aini, Q. (2016). IDENTIFIKASI PERMASALAHAN PEMBELAJARAN MAHASISWA PENDIDIKAN MATEMATIKA PADA MATA KULIAH PROGRAM LINEAR: STUDI KASUS PADA PROGRAM STUDI PENDIDIKAN MATEMATIKA. JURNAL TATSQIF, 14(1), 33-48.

\section{PENDAHULUAN}

Program linear merupakan salah satu mata kuliah wajib dari Program studi Pendidikan Matematika (jurusan Pendidikan Matematika) pada beberapa PTN/PTS di Pulau Lombok yang banyak membahas tentang masalah dikehidupan sehari-hari tentu yang berkaitan dengan perhitungan, seperti dalam berwirausaha. Dalam berwirausaha seorang pasti ingin mendapatkan keuntungan atau laba yang besar (maksimum), maka program linear dapat digunakan untuk menghitung laba maksimum yang bisa diperoleh seorang yang berwirausaha. Selain menguasai teori di bangku kuliah, diharapkan mahasiswa juga bisa memiliki jiwa menciptakan sendiri lapangan pekerjaan. Terbatasnya lapangan pekerjaan membuat kita harus bisa mempunyai jiwa untuk menciptakan lapangan pekerjaan baru. Langkah ini merupakan salah satu cara untuk menumbuhkan jiwa entrepreneurship di kalangan mahasiswa, sehingga akan mendorong tumbuhnya perekonomian indonesia terutama di bidang ekonomi kreatif.

Berdasarkan hasil pengamatan pada beberapa PTN/PTS di Pulau Lombok ditemukan fakta bahwa mata kuliah program linear, terutama materi model matematika dan metode simpleks, termasuk materi yang cukup sulit serta memerlukan tingkat penalaran dan kemampuan komunikasi yang tinggi untuk bisa dimengerti. Terutama dalam memforulasikan masalah ke dalam model matematika. Begitu juga untuk materi pemecahan masalah program linear dengan metode simpleks juga sangat sulit dipahami. Padahal kenyataannya, materi Program Linear yang terdiri dari persamaan linear, pertidaksamaan linear dan aljabar linear adalah sangat esensial sebagai materi prasyarat dari beberapa mata kuliah lainnya seperti mata kuliah Statistika Matematika, Kapita Selekta, dan sebagainya. Hal ini dapat dilihat dari Silabus ataupun SAP (Satuan Acara Perkuliahan) Program Linear di dalam Kurikulum Program Studi Pendidikan Matematika (Jurusan Pendidikan Matematika) di beberapa PTN dan PTS sepulau Lombok.

Assessment terhadap proses pembelajaran perlu secara rutin 
Saparwadi, L. \& Aini, Q. (2016). IDENTIFIKASI PERMASALAHAN PEMBELAJARAN MAHASISWA PENDIDIKAN MATEMATIKA PADA MATA KULIAH PROGRAM LINEAR: STUDI KASUS PADA PROGRAM STUDI PENDIDIKAN MATEMATIKA. JURNAL TATSQIF, 14(1), 33-48.

dilaksanakan dalam rangka peningkatan metode pembelajaran dan penyesuaian tuntutan kompetensi pembelajaran yang ada. Penyusunan Silabus, SAP, Modul, Metode dan penetapan alat bantu pengajaran harus selalu dievaluasi secara berkala dalam rangka keberhasilan proses pembelajaran. Seiring dengan kemajuan teknologi informasi yang begitu cepat, penyebaran informasi baik itu teks, data, gambar, dan lain sebagainya dapat dilaksanakan dengan cepat, tepat dan akurat kepada pengguna informasi tersebut, sehingga akhirnya akan meningkatkan produktivitas.

Sejalan dengan itu, perlu dirancang sebuah strategi pembelajaran yang menyisipkan beberapa pengetahuan dari beberpapa disiplin ilmu lain untuk mengantisipasi kenyataan yang ada karena Program Linear merupakan mata kuliah yang harus diajarkan pada disiplin ilmu lain, selain mata kuliah Statistika, diantaranya pada Fakultas MIPA, Fakultas Ekonomi, dan lain sebagainya. Oleh karena itu, sekali lagi, perlu dicari cara untuk dapat mengajarkan materi Program Linear menjadi mudah dipahami dan dipelajari, dan tentunya harus dibuat lebih menarik.

\section{LANDASAN TEORI}

\section{Belajar dan Pembelajaran}

Belajar adalah suatu aktivitas atau suatu proses untuk memperoleh pengethuan, meningkatkan keterampilan, memperbaiki prilaku, sikap, dan menokohkan kepribadian. Dalam konteks menjadi tahu atau proses memperoleh pengethuan, menurut pemahan sains konvensional, kontak manusia dengan alam diistilahkan dengan pengalaman (experience). Pengalaman yang terjadi berulang kali melahirkan pengetahuan (knowledge), atau a body of knowledge (Suyono dan Hariyanto, 2011;9). Istilah belajar sudah tidak asing lagi dengan kehidupan kita sehari-hari. Di masyarakat, kita sering menjumpai penggunaan istilah belajar seperti: belajar berbicara, belajar membaca, belajar berhitung. Masih banyak lagi penggunaan istilah belajar, bahkan termasuk kegiatan belajar yang 
sifatnya lebih umum dan tak mudah diamati, seperti: belajar hidup mandiri, belajar menghargai waktu, belajar bermasyarakat dan sejenisnya.

Belajar adalah suatu proses usaha yang dilakukan sesorang untuk memperoleh perubahan tingkah laku yang baru secara keseluruhan sebagai hasil pengalamannya sendiri dalam interaksi dengan lingkungannya (Hamdani, 2011;20). Di lain pihak, Morgan mengatakan bahwa belajar adalah perubahan perilaku yang bersifat permanen sebagai hasil dari pengalaman (Agus Suprijono: 2010;3).

Berdasarkan beberapa pendapat di atas, belajar adalah sebuah proses aktivitas yang terjadi guna memperoleh pengetahuan yang berakibat terjadi perubahan perilaku ke arah yang lebih baik.

Pembelajaran merupakan proses dua arah, mengajar dilakukan oleh pihak guru sebagai pendidik, sedangkan belajar dilakukan peserta didik atau murid. Konsep pembelajaran menurut Corey adalah suatu proses dimana lingkungan seseorang secara sengaja dikelola untuk memungkinkan ia turut serta dalam tingkah laku tertentu dalam kondisikondisi khusus atau menghasilkan respon terhadap situasi tertentu, pembelajaran merupakan bagian dari khusus dalam pendidikan (Irzani, 2010;1)

Pembelajaran merupakan upaya penataan lingkungan yang memberi nuansa agar program belajar tumbuh dan berkembang secara optimal (Erman Suherman dkk, 2003;7). Selain itu, menurut Yusufhadi Miarso, pembelajaran adalah suatu usaha yang disengaja, bertujuan, dan terkendali agar orang lain belajar atau terjadi prubahan yang relatif menetap pada diri orang lain. Uasaha tersebut dapat dilakukan oleh seseorang atau sekelompok orang yang memiliki kemampuan atau kompetensi dalam merancang dan mengembangkan sumber belajar yang diperlukan. Dapat juga dikatakan bahwa pembelajaran adalah usaha yang dilakukan oleh pendidik atau orang dewasa lainnya untuk membuat 
pembelajar dapat belajar dan mencapai hasil belajar yang maksimal. (Martinis Yamin, 2013;15)

Berdasarkan pendapat di atas, dapat ditarik kesimpulan bahwa pembelajaran merupakan suatu proses interaksi dua arah yang dilakukan secara sengaja, terkendali, dan memiliki tujuan untuk menghasilkan pengetahuan tertentu.

\section{Pembelajaran Program Linear}

Pembelajaran merupakan upaya untuk membelajarkan mahasiswa.Untuk mendapatkan hasil pembelajaran Program Linear yang memadai diperlukan kemampuan berpikir, dan bernalar serta adanya suatu pembelajaran yang bermutu. Dalam pembelajaran terkandung makna adanya suatu kegiatan untuk memiliki dan mengembangkan suatu metode, strategi, teknik atau pendekatan untuk mencapai hasil pembelajaran yang diharapkan.

Program linear adalah salah satu cabang dari matematika yang sangat penting dan banyak diterapkan secara luas dalam mengambil sebuah keputusan dalam berbagai bidang permasalahan, misalnya permasalahan di bidang pertanian, kesehatan, ekonomi, dan lain sebagainya. Secara garis besar, program linear merupakan suatu metode untuk membuat keputusan di antara berbagai alternative kegiatan pada waktu kegiatan-kegiatan tersebut dibatasi oleh kendala-kendala tertentu. Keputusan yang akan diambil dinyatakan sebagai fungsi tujuan sedangkan kendala-kendala yang dihadapi dalam membuat keputusan tersebut dinyatakan dalam bentuk fungsi-fungsi kendala. Sesuai dengan nama model program linear, maka fungsi tujuan dan fungsi-fungsi kendala tersebut harus berupa fungsi yang linear, baik dalam bentuk persamaan maupun pertidaksamaan pada variable-variabel keputusannya. 


\section{METODE}

\section{Jenis penelitian}

Secara umum penelitian ini termasuk dalam penelitian pengembangan, yaitu penelitian yang memiliki tujuan untuk mengembangkan produk pendidikan dan proses pengambilan keputusan selama pengembangan produk guna meningkatkan kualitas produk yang dihasilkan dan mampu menciptakn produk yang sejenis di masa akan datang. Secara khusus penelitian ini merupakan penelitian kualitatif dekriptif dengan menggunakan aturan penelitian pengembangan.

\section{Populasi dan Sampel Penelitian}

Populasi penelitian ini adalah seluruh mahasiswa Program Studi Pendidikan Matematika PTN/PTS se-pulau Lombok. Untuk menentukan jumlah mahasiswa yang akan menjadi sampel penelitian ini pada setiap kelas, maka setiap narasumber dipilih berdasarkan kriteria yang ditentukan. Berdasarkan hal tersebut, kriteria mahasiswa yang menjadi sasaran penelitian, yaitu (1) mahasiswa yang sedang mengikuti matakuliah program linear; (2) dosen pengampu matakuliah program linear.

\section{Penetapan Informan}

Informan yang akan dilibatkan dalam penelitian ini, yaitu Dosen pengampu matakuliah program linear dan mahasiswa yang sedang mengikuti matakuliah program linear.

\section{Teknik Pengumpulan Data dan Analisis Data}

Teknik pengumpulan data yang akan diterapkan dalam penelitian ini adalah wawancara, analisis dokumen, dan observasi. Berdasarkan teknik pengumpulan data tersebut, dapat diperoleh data kualitatif. Data kualitatif dianalisis dengan menggunakan teknik analisis deskripsi yang dilakukan secara berkelanjutan sesuai data yang diperoleh.

\section{Tahap identifikasi masalah dan kebutuhan}


Penelitian ini bertujuan untuk mengetahui masalah yang ditemukan, serta hal-hal yang dibutuhkan dalam pembelajaran, dan manfaat dalam pembelajaran program linear pada mahasiswa pendidikan matematika yang sedang mengikuti perkuliah program linear pada beberapa perguruan tinggi di pulau Lombok. Untuk mencapai tujuan tersebut, maka kegiatan yang dilakukan meliputi identifikasi masalah, kebutuhan dalam pelaksanaan pembelajaran, dan manfaat yang diperoleh setelah mengikuti pembelajaran program linear. Data dikumpulkan melalui teknik wawancara tentang masalah, kebutuhan pembelajaran, dan maanfaat yang diperoleh setelah pembelajaran terutama aplikasinya dalam kehidupan sehari-hari dengan dosen dan mahasiswa peserta perkuliahan, khususnya mahasiswa pendidikan matematika.

\section{HASIL DAN PEMBAHASAN}

Capaian hasil yang dibahas dalam bagian ini adalah capaian yang berhubungan dengan tujuan penelitian tahun pertama. Terdapat dua tujuan dalam penelitian pada tahun pertama ini, yaitu mengidetifikasi hasil surve di lapangan yang berupa temuan permasalahan yang di hadapai mahasiswa dalam mempelajari materi di mata kuliah program linear, dan mencari solusi dari permasalah tersebut melalui pengembangan model pembelajaran yang dilengkapi dengan mudul pembelajaran program linear yang dapat membantu mahasiswa dalam memecahkan berbagai permasalahan yang berkaitan dengan materi di mata kuliah program linear. Oleh karena itu, sebelum kita melakukan sebuah pengembangan pembelajaran, maka terlebih dahulu kita menganalisis hasil surve identifikasi masalah yang dihadapi mahasiswa selama belajar program linear.

Bentuk permasalahan yang dihadapi mahasiswa program studi pendidikan matematika, setelah para peneliti melakukan surve dan mengadakan diskusi terarah pada beberapa mahaiswa dari tiga perguruan tinggi yang berbeda dan sedang memprogramkan mata kuliah program 
Saparwadi, L. \& Aini, Q. (2016). IDENTIFIKASI PERMASALAHAN PEMBELAJARAN MAHASISWA PENDIDIKAN MATEMATIKA PADA MATA KULIAH PROGRAM LINEAR: STUDI KASUS PADA PROGRAM STUDI PENDIDIKAN MATEMATIKA. JURNAL TATSQIF, 14(1), 33-48.

linear di semester genap, yaitu STKIP Hamzanwadi Selong, Universitas Muhammadiah Mataram, dan IAIN Mataram. Mata kuliah program linear di Program Studi Pendidikan Matematika STKIP Hamzanwadi Selong di ampu oleh dua dosen, untuk jurusan Pendidikan Matematika Universitas Muhammadiah Mataram mata kuliah program linear hanya diampu oleh satu dosen, dan IAIN Mataram di ampu oleh satu dosen. Permasalahan yang diperoleh berdasarkan hasil wawan cari dari perwakilan mahasiswa dari masing-masing perwakilan dan dosen pengampu dapat digolongkan menjadi 4, yaitu a) kesulitn mendapat materi; b) keulitan memahami materi; c) strategi pembelajaran yang biasa digunakan di mata kuliah program linear; dan d) hasil atau manfaat yang dapat diperoleh setelah mempelajari materi di mata kuliah program linear.

\section{Kesulitn Mendapat Materi}

Untuk menjalankan proses belajar-mengajar, tentunya materi yang akan dipelajari harus siap, baik dari dosen sebagai penyampaikan atau pemberi materi maupun mahasiswa yang akan sebagai penerima penjelasan materi dari dosen pengampu. Materi pelajaran tidak bisa terlepas dari mana bahan materi diperoleh yaitu salah satunya refernsi yang diperoleh dari buku acuan yang akan digunakan oleh dosen. Tentunya mahasiswa harus tau buku acuan utama maupun tamban yang akan digunakan dosen pengampu mata kuliah. Tapi kenyataannya sebagian besar dosen sebagai pengampu mata kuliah program linear menggunakan atau mendapatkan bahan materi dari buku-buku sekolah tingkat SLTP, SLTA, dan bahkan ada yang dari internet. Penggunaan materi perkuliahan dari buku matematika sekolah tingkat SLTP dan SLTA sebenarnya tidak menyulitkan mahasiswa untuk mendapatkan bahan materinya, tapi pengetahuan yang mahasiswa miliki tidak bisa berkembang, sehingga ketika mahasiswa menghadapi masalah luas maka mahasiswa akan sulit menemukan solusinya. Pada dasarnya materi mata kuliah program linear banyak membahas masalah kehidupan nyata 
di lingkungan sekitar mereka terutama masalah ekonomi. Pandangan ini juga dipertegas berdasarkan hasil wawancara yang dilakukan peneliti dengan lima dosen pengampu mata kuliah program linear dari 3 perguruan tinggi berbeda yang sedang menjalankan perkuliahan seperti berikut ini:

Materi program linear merupakan materi yang isinya kebanyakan materi persamaan linier yang ada di tingkat SMP (MTs), materi pertidaksamaan linear dan program linear yang ada di tingkat SMA (MA). Jadi mahasiswa tidak kesulitan mendapat materi itu, dan tinggal kita arahkan saja untuk membuka kembali materi matematika yang ada di tingkat SMP dan SMA. Selanjutnya itu dibahas dan dicari penyelesaiannya baik dengan metode grafik maupun simpleks. (Pernyataan dosen 1)

Materi program linear mahasiswa bisa lihat di buku-buku SMA dan di situ sudah ada semua. Tinggal kita tambahakan materi simpleknya saja. Buku yang membahas masalah program linear untuk tingkat mahasiswa juga sulit kita tenukan. (Pernyataan dosen 2)

Buku yang membahas khusus program linear sangat sulit kita temukan, sehingga materi yang saya sampaikan, saya ambil dari buku SMA saja dan tinggal kita tambahkan pemecahannya menggunakan metode simpleks saja. (Pernyataan dosen 3).

Buku program linear sangat sulit ditemukan, saya biasa mengguanakan buku tentang matriks dan disitu membahas masalah program linear terutama dalam metode simplek. Dari buku itu menurut saya cepat dipahami aturan pemecahan masalah terutama dimetode simpleksnya. (pernyataan dosen 4).

Saya biasa menggunakan buku ini yang berjudul "Program Linear" karangan Sudirman dengan penerbit UM Press. Selain itu saya membagikan diktat yang difoto copy mahasiswa dan itu saya arahkan untuk didiskusikan. (pernyataan dosen 5)

Pernyataan lima dosen tersebut juga cukup dikuatkan dari hasil wawancara mahasiswa perwakilan dari tiga perguruan tinggi berbeda, seperti berikut: 
Saya sulit menemukan buku yang khusus membahas masalah program linear, sehingga saya bersama teman-teman di kelas kebanyakan mendapat materi tergantung yang diberikan dari dosen. (Mahasiswa 1)

Saya diberikan silabus, materi perkuliahan tergantung dari dosen berupa foto copy (Mahasiswa 2).

Saya hanya diberikan materi dalam bentuk foto copi dan saya tidak bisa menemukan buku program linear. (Mahasiswa 3)

Dari hasil wawancara baik dari dosen pengampu maupun dari mahasiswa yang sedang mengikuti perkuliahan di mata kuliah program linear disimpulkan bahwa buku yang membahas khusunya masalah program linear masih cukup sulit ditemukan dan berdasarkan hasil survei pada toko buku di pulau Lombok juga masih sulit ditemukan keberadaan buku yang membahas khusus masalah program linear. Sulitnya ditemukan buku program linear sebagai refrensi bagi mahasiswa di mata kuliah program linear membuat mahasiswa khususnya di program studi pendidikan matematika cukup sulit mengembangkan pengetahuan yang mereka miliki, sehingga berakibat akan menurunya prestasi yang mereka miliki terutama di mata kuliah program linear.

\section{Kesulitan Memahami Materi}

Mata kuliah program linear memiliki sub pokok bahasan yang membuat mahasiswa sangat sulit mencari solusinya selain mengenai penyelesaian metode simpleks yaitu juga dalam pemodelan matematika. Materi pemodelan matematika ini merupakan materi inti pertama yang banyak disampaikan oleh pengampu di mata kuliah program liniear, dan materi ini sebagian besar mahasiswa mengalami kesulitan dalam mendefinisikan dan membentuk masalah menjadi model matematika, baik dalam menetukan fungsi tujuan maupun fungsi kendala. Pernyataan ini diperkuat oleh pernyataan mahasiswa yang menjadi target wawancara seperti berikut. 
Susah menentukan tujuan soal cerita ketika membuat model matematka (pernyataan mahasiswa 1)

Dalam membuat model matematika dari sebuah permasalah yang disusun dalam soal cerita dibutuhkan pemehaman mahasiswa mengenai kondisi permasalah berdasarkan materi yang dibahas. Materi yang dibahas sebagian besar membahas masalah prekonomian walupun bidang pembahasanya berbeda, seperti prekonomian didunia pertanian, perikanan, properti, dan lain sebagainya. Setiap kita membahas masalah prekonomian baik dalam bentuk perencanaan, penjualan, maupun pembelian selalu ada tujuan yang ingin dicapai. Untuk memperoleh sebuah tujuan tentunya selalu ada kendala-kendala yang perlu diperhatikan. Untuk memudahkan mendeteksi kendala-kendala yang mencul dalam sebuah permasalah ketika meujudkan tujuan yang diinginkan, maka perlu dirancang sebuah model permasalah yang disusun dalam model matematika. Membuat model matematika, terlebih dahulu ditentukan berapa jenis variabel yang dibutuhkan. Untuk pemodelan matematika dua variabel, maka solusi pemecahannya paling mudah yaitu dengan metode grafik. Metode grafik ini dibutuhkan pemahaman konsep pada persamaan dan pertidaksamaan linear serta grafiknya, dan materi ini sudah dipelajari sejak mahasiswa menginjak bangku sekolah ditingkat SLTP. Tapi kenyataannya, masih banyak mahasiswa kesulitan dalam hal ini ketika disuruh membuat grafik persamaan dan pertidaksamaan linier. Hal ini diperkuat berdasarkan kutipan wawancara dari pernyatan dua mahasiswa seperti berikut.

Sulit dalam membuat grafik, dan Kendala dalam pemodelan sulit menentukan variabelnya. (Mahasiswa 2)

Menetukan kendala dalam pemodelan dan Kesulitan dalam membuat grafik. (mahasiswa ke-3)

Saya tidak dijelaskan secara detail tentang pemodelan matematika dan penyelesaian metode grafik, saya cuman dikasik materi matrik 
dan simpleks, sehingga saya sulit memahami materi yang diberikan oleh dosen. (mahasiswa ke-4)

Dari kutipan wawancara tersebut, mahasiswa di program studi pendidikan matematika perlu dibekali sebuah pemahaman konsep dasar sebelum memulai perkuliahan pada materi yang akan dibahas. Untuk membuat model matematika, maka seorang dosen perlu memberikan pengetahuan tambahan mengenai materi permasalah baik dibidang prekonomian, pertanian, dan lainnya berdasarkan pengkajian konsep permasalahan yang akan dipecahkan. Khusus pernyataan mahasiswa yang ke empat, ini menunjukan dosen pengampu mata kuliah program linear tidak menyampaikan materi sesuai dengan silabus yang diberikan kepada mahasiswa. Hal seperti ini harus tetap dievaluasi oleh ketua program studi, agar tidak merugikan mahasiswa kedepannya.

\section{Strategi Pembelajaran}

Untuk mencapai hasil pembelajaran yang diinginkan sesuai dengan standar yang ditetapkan, maka dibutuhkan perbaikan dari proses pembelajaran. Proses pembelajaran tidak terlepas dari strategi atau metode apa yang digunakan dalam menjalankan proses dari pembelajaran tersebut. Strategi yang digunakan oleh dosen selama ini dalam pembelajaran program linear sebagian besar mahasiswa gagal dalam menerjemahkan masalah menjadi model matematika. Ini karenakan ada beberapa dosen hanya memberikan masalah yang harus dipecahkan kepada mahasiswa baik secara diskusi maupun secara mandiri tanpa memperhatikan letak kesulitan mahasiswa dalam menerjemahkan maksud dari permasalahan soal cerita yang diberikan oleh dosen pengampu. Oleh karena itu, menerapkan sebuah strategi dalam pembelajaran dibutuhkan perencanaan dengan mempertimbagkan jenis materi yang akan disampaikan. Pemilihan strategi pembelajaran yang tidak sesuai dengan materi yang dibahas, maka akan menyulitkan mahasiswa sebagai penerima pengetahuan dari 
dosen dalam memahami materi di bangku kuliah. Hal tersebut berdasarkan pernyataan mahasiswa sebagai berikut.

Cara dosen saya mengajara biasa aja, dikasi materi dalam bentuk fotocopian, dijelaskan sedikit, dan duduk. Itu saja dan kami jarang belajar menggunakan cara diskusi di kelas atau dengan pendekatan apapun. (pernyataan mahasiswa 1)

Strategi yang digunakan dosen saya yaitu dengan terlebih dahulu diberikan materinya dan soal, setelah itu saya diskusikan dengan teman di kelas. (pernyataan mahasiswa ke-2)

Berdasarkan pernyataan mahasiswa tersebut, maka seorang dosen harus bisa memilih dan mengunakan startegi yang tepat agar materi yang disampaikan mudah dipahami oleh mahasiswa. Sesuai dengan pendapat Kemp (1995) dalam Wina Sanjaya (2010: 126) menjelaskan bahwa strategi pembelajaran adalah suatu kegiatan pembelajaran yang harus dikerjakan guru dan siswa agar tujuan pembelajaran dapat dicapai secara efektif dan efisien. Oleh karena itu, penggunaan strategi pembelajaran harus diperhatikan untuk dapat mengimplementasikan rencana pembelajaran yang disusun sebelumnya agar tujuan yang telah tersusun dapat tercapai secara optimal.

\section{Manfaat Belajar Program Linear}

Program linear merupakan mata kuliah di program studi pendidikan matematika dan merupakan pondasi awal sebelum masuk mata kuliah riset operasi yang merupakan mata kuliah pilihan pada beberapa perguruan tinggi yang memiliki program studi pendidikan matematika di pulau Lombok. Riset operasi ini membahas bagaimana memecahkan permasalah dalam mencapai tujuan yang diinginkan berdasarkan kendala-kendala yang ada. Mata kuliah riset operasi ini juga banyak digunakan dalam perencanaan sebuah kebijakan sebelum mengambil keputusan dalam sebuah tindakan, sehingga mata kuliah ini juga dipelajari oleh bidang ilmu di luar bidang baik matematika maupun di 
luar pendidikan matematika. Besarnya manfaat mempelajari materi di mata kuliah riset operasi sejalan dengan besarnya manfaat mempelajari mata kuliah program linear di proram studi pendidikan matematika. Karena tidak semua perguruan tinggi di pulau Lombok memprogramkan riset operasi sebagai mata kuliah di program studi pendidikan matematika. Besarnya manfaat mempelajari mata kuliah program linear tidak banyak diketahui oleh mahasiswa yang sedang mengikutinya. Mahasiswa hanya tau bagai mana cara membuat grafik dengan baik, bisa menentukan untung atau rugi dalam perdagangan, dan ini di perkuat berdasarkan pernyataan mahasiswa berikut ini.

Bisa membuat grafik dengan baik dan dengan materi pemodelan bisa menentukan untung dan rugi. (Mahasiswa 1)

Mengetahui hasil maksimum dan minimum. (Mahasiswa ke-2)

Lebih mengetahui grafik misalnya dalam perdagangan bisa diketahui grafik keuntungan dan kerugian. (Mahasiswa ke-3)

Kutipan dari tiga pernyataan mahasiswa di atas masih bisa menyebutkan manfaatnya walupun secara teori, tapi pernyataan mahasiswa berikut ini tidak tau manfaat setelah belajar mata kuliah program linear. berdasarkan hasil kutipan wawancara sebelumnya bahawa mahasiswa tersebut hanya diberikan materi matrik dan simpleks, sedangkan pemodelan matematika hanya sekedar disinggung saja sedikit dan penyelesaian mtode grafik tidak dijelaskan, dan berikut pernyataannya.

Saya tidak tau manfaat kedepannya setelah mempelajari mata kuliah program linear (mahasiswa ke-4)

Sebagian besar mahasiswa tidak tau manfaat secara aplikasi terutama berkaitan dengan kegiatan kehidupan nyata setelah mempelajari program linear berdasarkan hasil wawancara yang dilakukan. Terlihat mahasiswa hanya mengetahui manfaat yang 
Saparwadi, L. \& Aini, Q. (2016). IDENTIFIKASI PERMASALAHAN PEMBELAJARAN MAHASISWA PENDIDIKAN MATEMATIKA PADA MATA KULIAH PROGRAM LINEAR: STUDI KASUS PADA PROGRAM STUDI PENDIDIKAN MATEMATIKA. JURNAL TATSQIF, 14(1), 33-48.

diperoleh serputar pemahaman dalam setiap sub pokok bahasan di mata kuliah program linear, dan tidak bisa mengetahui maanfaat yang lebih luas baik dibidang ekonomi maupun bidang yang lainnya. Setiap menyampaikan materi dari sebuah mata kuliah, hendaknya seorang dosen sangat perlu menyampaikan manfaat yang akan diperoleh secara luas setelah mempelajari materi yang akan dipelajari mahasiswa. Mengingat materi program linear sebagaian besar membahas masalah ekonomi, sehingga menyampaikan manfaat sebelum memulai perkuliahan maupun ketika sedang perkuliahan berlangsung. Hal ini berfungsi selain dalam membankitkan minat belajar mahasiswa juga akan menumbuhkan jiwa entrepreneurship mahasiswa kedepannya.

\section{KESIMPULAN}

Demi tercapainya sebuah hasil pembelajaran yang diinginkan sesuai dengan ketercapaian indikator pembelajaran, dibutuhkan perbaikan baik dari persiapan, pemilihan metode atau pendekatan yang digunakan, maupun bahan ajar yang dibutuhkan. Mengingat program linear maerupakan mata kuliah yang sangat bermanfaat baik dalam pemecahan masalah maupun dalam perencanaan dalam pengambilan keputusan, membutuhkan pengetahuan tambahan sebagai penguat dalam pemahaman konsep materi program linear. Dalam materi program linear banyak memberikan permasalahan ekonomi terutama ekonomi kecil dan menegah. Masalah ekonomi kecil dan menegah ini termuat dalam sistem ekonomi keratif yang terbangun dari industri kreatif. Untuk mempermudah dalam memberikan tambahan tentang ekonomi kreatif ini, peneliti menganggap sudah saatnya dikembangkan sebuah pembelajaran di mata kuliah program linear ini berbasis ekonomi kreatif dengan pendekatan kontruktivisme. Pendekatan kotruktivisme ini dipilih bertujuan untuk memberdayakan pengetahwan yang ada dalam diri mahasiswa itu sendiri untuk dikembangkan dalam penyelasaian masalah dengan berbagai strategi guna mendapatkan hasil yang sebenarnya, sehingga akan menumbuhkan jiwa entrepreneurship mahasiswa di program studi pendidikan matematika. 
Saparwadi, L. \& Aini, Q. (2016). IDENTIFIKASI PERMASALAHAN PEMBELAJARAN MAHASISWA PENDIDIKAN MATEMATIKA PADA MATA KULIAH PROGRAM LINEAR: STUDI KASUS PADA PROGRAM STUDI PENDIDIKAN MATEMATIKA. JURNAL TATSQIF, 14(1), 33-48.

\section{DAFTAR PUSTAKA}

Agus Suprijono. (2010). Cooperative Learning Teori dan Aplikasi PAIKEM. Yogyakarta: Pustaka Pelajar.

Elis Sondayani, 2013. Perencanaan Ekonomi Kreatif Bagi Wirausawan. Jurnal media komunikasi (warta bapeda), volume 21 No. 4 Desember 2013.

Ety Septiati, 2012. Keefektifan Pendekatan Konstruktivisme Terhadap Kemampuan Koneksi Matematis Mahasiswa Pada Mata Kuliah Analisis Real I. Prosiding Seminar Nasional Matematika dan Pendidikan Matematika FMIPA UNY Yogyakarta, 10 November 2012

Erman Suherman, dkk. (2003). Strategi Pembelajaran Matematika Kontemporer. Bandung: Universitas Pendidikan Indonesia.

Hamdani. (2011). Strategi Belajar Mengajar. Bandung: CV Pustaka Setia.

Irzani. (2010). Pembelajaran Matematika. Yogyakarta: Media Grapindo Press.

Martinis Yamin. (2013). Strategi dan Metode dalam Model Pembelajaran. Jakarta: Referensi.

Sumaryanto, 2012. Pembinaan Mahasiswa Menuju Wirausahawan Yang Unggul. Diklat PMW di Kaliurang Tanggal 29 Mei 2012

Suyono, dkk. (2011). Belajar dan Pembelajaran. Bandung: Remaja Rosdakarya Sugiyono, 2007. Statistika Untuk Penelitian. Bandung : CV Alfabeta.

Sugiyono, 2007. Metode penelitian pendidikan: pendekatan kuantitatif, kualitatif, dan $R \& D$. Bandung: Penerbit Alfabeta.

Wina Sanjaya. (2010). Strategi pembelajaran berorientasi standar proses pendidikan. Jakarta: Kencana. 